\title{
IMPLEMENTING THE E-FAMILY EXPERT MODEL THROUGH A LEGAL FRAMEWORK FOR ONLINE DISPUTE RESOLUTION
}

\author{
Zaleha Kamaruddin* \\ Umar A. Oseni** \\ Zati Ilham Abdul Manaf***
}

\begin{abstract}
With the protracted COVID-19 pandemic ravaging the world, and new virulent variants emerging all the time, there has been massive pressure applied to family institutions, particularly in the Muslim world. These pressures include domestic violence, increased divorce rates, and increased spouse mortality, all of which have triggered unique family disputes. With restrictions on movement and physical distancing measures in place, one wonders whether there are new, alternative means to resolve such budding family-related disputes. To address this issue, this paper examines the potential of the E-Family Expert Model, earlier designed by the authors, to resolve family-related disputes under the legal framework of Online Dispute Resolution (ODR). The study adopts an analytical approach via a qualitative research methodology to discuss the relevant issues with a view to finding a lasting solution to family dispute resolution within a pandemic environment. One of the study's major findings relates to the relevance of the Fourth Industrial Revolution for implementing the E-Family Expert Model, where the usual boundaries between the physical, digital, and biological are strategically blurred with the implementation of a family ODR platform. The study concludes that the E-Family Expert Model could help a great deal in addressing a multitude of family-related disputes through an ODR platform, while complying with national legislative frameworks. This could further be a tool for member states of the Organization of Islamic Cooperation $(\mathrm{OIC})$ to address increasing numbers of family disputes using a more formalised framework.
\end{abstract}

Keywords: E-Family Expert Model, family disputes, family dispute resolution, Online Dispute Resolution, alternative dispute resolution.

\section{Introduction}

The COVID-19 pandemic has fast tracked the adoption of technology 
in various aspects of life, including in the financial, legal, industrial, and business sectors. Another sector that has also seen major changes is the family institution, where family members have become separated due to travel restrictions and had to resort to virtual meetings. While virtual interactions have provided individuals with an opportunity to interact with their loved ones during the pandemic, a rise in domestic violence and divorce cases across the world has also emerged due to family implosion exacerbated by lockdowns and movement restrictions. In a recent study jointly undertaken by the United Nations Population Fund (UNFPA), UN Women, and Quilt.AI, an analytics company, the following eight countries were surveyed: Bangladesh, India, Indonesia, Malaysia, Nepal, the Philippines, Singapore, and Thailand. ${ }^{1}$ The focus of the study was to identify trends between September 2019 and November 2020 in internet searches relating to both violence against women and help-seeking during the COVID-19 lockdown. The study revealed that such searches rose tremendously. For instance, searches related to physical violence (such as "spouse abuse" or "men hitting women", among others) in three countries - Malaysia, Nepal, and the Philippines - increased by 47 per cent, 55 per cent, and 63 per cent respectively. The report therefore suggested that the governmental and private sectors of these countries consider active online engagement with people facing domestic violence, in addition to survivors who require immediate help. ${ }^{2}$ This is an example of how Big Data analysis can help solve a perennial social problem.

Even before the COVID-19 pandemic, increasing cases of domestic violence and divorce rates in Muslim societies had prompted efforts within a dedicated family law research group at the International Islamic University of Malaysia (IIUM) to develop an internet-based solution for people seeking assistance when facing these issues. ${ }^{3}$ In furtherance to such efforts, and with the principal objective of providing a neutral platform establishing an inextricable link between family law experts and those seeking help, this study provides an overview of the integrated E-Family Expert Model. The role of family law experts and counsellors in operationalising this innovative system for managing family-related issues cannot be overemphasised at a time when domestic violence and divorce cases are skyrocketing. This study seeks to assess existing mechanisms for the E-Family Expert Model and its relevance as a unique form of Online Dispute Resolution (ODR). The research is expected to provide an avenue for couples seeking advice from experts at their convenience. With early intervention, it may save marriages from imminent collapse. The socio-legal impact of this research on the economy and national well-being will help build a formidable family institution capable of promoting a peaceful and cohesive society. 


\section{Family Disputes and Online Dispute Resolution}

In its simplest form, ODR is the utilisation of Information and Communication Technology (ICT) to help manage disputes, including avoidance and resolution protocols. ODR emerged as early as the 1990s as a form of dispute resolution within online marketplaces. ${ }^{4}$ It has since extended into other forms of dispute, with courts adopting it in full for formal court proceedings involving a variety of subject matters. With the pandemic hitting the world, people are getting more comfortable with utilising ICT as a means of resolving disputes; in most cases, they have been compelled to use them for court proceedings.

\section{Utilising ODR for Family Disputes}

According to Katsh, one of the very earliest significant experiments in ODR took place at the University of Maryland, in association with their Family Law Project. Thus, the origin of ODR lies in family-related disputes. The Maryland project proposed an online platform for family disputes when couples were located in different geographical locations, making it impossible to bring them together physically. ${ }^{5}$ This early initiate triggered other experiments across the world. Notable among these were significant reforms in Australia: within the context of nine other ODR processes focused on family disputes, ${ }^{6}$ Australia's Attorney General Department funded research on Online Family Dispute Resolution (OFDR) in 2009. ${ }^{7}$ The final report produced by this project, submitted on 30 March 2011, included significant recommendations for user accessibility and usability, with additional suggestions concerning project management. ${ }^{8}$ Within the context of the present research, their use of the Customer Relationship Management (CRM) analytic model when developing online access to experts is particularly pertinent. ${ }^{9}$ This socio-legal element has not been previously used when addressing family related issues; its relevance for seeking expert opinion online, however, particularly during distressful times, when there seems to be no one to turn to for advice, is clear. ${ }^{10}$

Across the world, there are currently several ODR firms supporting clients facing family disputes, particularly divorce cases. Existing online platforms include: HelloDivorce.com, Wevorce.com, OurFamilyWizard.com, CommonSenseDivorce.com, ItsOverEasy.com, and CoParenter.com. ${ }^{11}$ From an initial analysis of these existing platforms, it is clear that none have adopted Islamic law principles. There is, in short, no known formal platform for ODR in family dispute cases in the Muslim world. This makes a compelling case for the proposed E-Family Expert Model outlined here. 


\section{Family Lawyers and Online Family Dispute Resolution}

The major concern when discussing ODR in the context of family disputes is whether this form of dispute settlement will adversely affect lawyers. It is argued that ODR would generate new opportunities for obtaining legal advice without recourse to traditional legal practitioners. Nevertheless, experts highlight how ODR is most often utilised by low income individuals, who would not be able to afford the cost of hiring lawyers, anyway. ${ }^{12}$ However, there was a noticeable paradigm shift during the pandemic, when even the rich began utilising ODR due to travel restrictions, as well as the ease and timeliness of the process. Such clients, however, still need to hire lawyers, who make their appearances online during mediation, arbitration, or litigation. Family disputes require deep knowledge of the law and legal system; whether one is engaging in online mediation or arbitration, one still requires legal guidance. This was seen during the recent lockdowns, when many courts moved their proceedings online, enabling lawyers to charge fees and provide legal services to clients via the internet. One would therefore conclude that, with the implementation of the E-Family Expert Model, family lawyers would make more money, potentially increasing their number of clients while spending less time on the job as they would not be required to commute.

\section{The Legality of Online Family Dispute Resolution in Islamic Law}

In Islamic law, the shariah prioritises efforts to diffuse marital discord and proactively resolve family-related disputes. Family law in general, and family dispute resolution in particular, are two core areas where the Qur'an gives explicit prescriptions. For instance, the Qur'an states:

If a wife fears cruelty or desertion on her husband's part, there is no blame on them if they arrange an amicable settlement between themselves; and such settlement is best; Even though men's souls are swayed by greed. But if ye do good and practise self-restraint, Allah is well-acquainted with all that ye do. (emphasis added) $)^{13}$

Taking into account the reason behind the revelation of this verse, some Muslim jurists explain that sulh (amicable dispute settlement) is most relevant in cases of marital discord. Certainly, the Qur'an pointedly provides further direction on the need for family arbitration during marital disputes:

If you fear a breach between them twain (the man and his wife), appoint (two) arbitrators, one from his family and the other from her's; if they 
both wish for peace, Allah will Cause their reconciliation. Indeed, Allah is ever All-Knower, Well-Acquainted with All things. ${ }^{14}$

In the exegesis of Ibn Kathir, it is emphasised that jurists have taken this verse to mean that, in the event of marital discord, it is the duty of the judge or family head to refer the parties (husband and wife) to a trusted third party who evaluates the dispute and guides the disputants to a negotiated settlement. It is usual to appoint reliable personalities from the two families to assist in reaching this amicable settlement. ${ }^{15}$

In the resolution of disputes more generally, Islamic law permits the use of all lawful means, including any ICT medium. Hence, ODR can be utilised for family disputes, since it is merely a medium or platform; the general Islamic legal principle of blocking the means to evil (sadd al-dharai') still applies. ${ }^{16}$ It is important to note that the "evil" referred to here is the budding marital discord or other family dispute. Any medium employed to resolve this is considered appropriate, provided its outcome complies with Islamic law. In fact, the whole idea of sadd al-dharai' is to tackle a problem before it grows into a full-blown conflict. Therefore, it provides a good basis for the use of the E-Family Expert Model.

\section{A Brief Overview of the Proposed E-Family Expert Model}

A major policy of every responsible government is the construction of a progressive and inclusive society. This includes strengthening the family institution, which is the principal objective of the E-Family Expert Model. The latter is a neutral platform connecting family law experts with those seeking assistance. It provides unprecedented free and fair access to top experts in family law, as well as to counselling, psychology, and religious teachings, using a dedicated online portal and smart phone app. This model is expected to complement the existing offline programmes currently being used in different countries across the Muslim world, particularly in Malaysia. The project is expected to provide an avenue for couples who are having martial problems and seek the views and advice of experts, at anytime or anywhere.

When designing the E-Family Expert Model, the current authors relied on the CRM analytic model, as illustrated in Figure 1. 


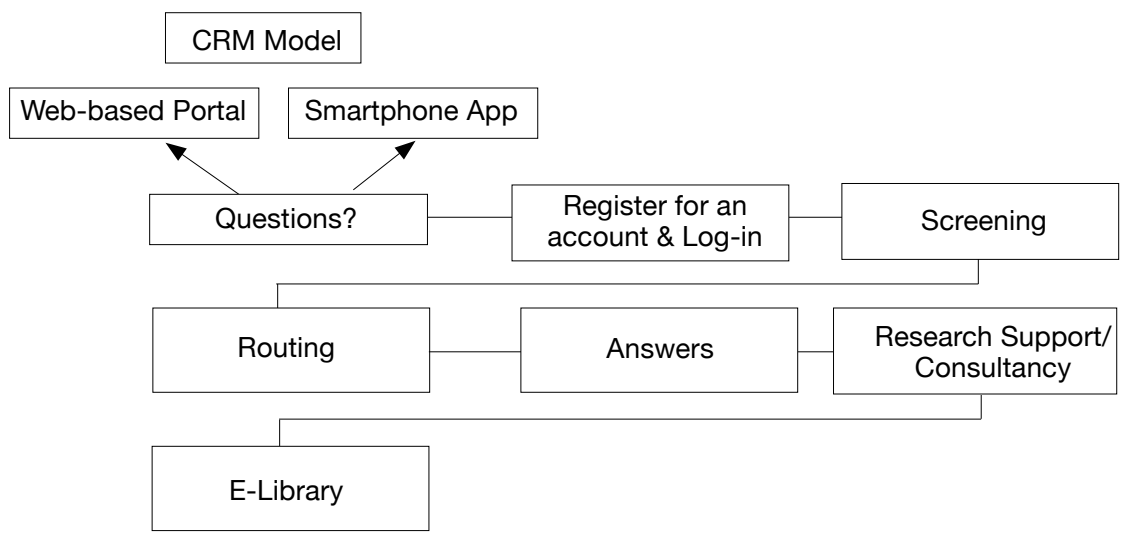

Figure 1: The E-Family Expert Model

Source: The authors

The platform involves: Questions, Screening and Routing, Answers, Consolidation, E-Library, and Research. In the first phase of this project, the CRM model was applied to allow for proper management of information among selected experts, including how that information would be visualised for users. The major features provided for in this first phase included: access to experts in family law, frequently asked questions, guides and tips for a successful marriage, online counselling services, and publications related to marital rights, duties, and obligations.

The mapping of the E-Family Expert website based on this first phase is provided in Table 1:

\begin{tabular}{|l|l|l|}
\hline & Page & Remarks \\
\hline 1. & Home Page & $\begin{array}{l}\text { Contains: Welcome Message, slideshow, features of the } \\
\text { site (call, chat, and conferencing). }\end{array}$ \\
\hline 2. & E-Info & Contains pdf files related to Islamic family laws. \\
\hline 3. & E-Experts & Brief information about experts. \\
\hline 4. & $\begin{array}{l}\text { Login and } \\
\text { Registration }\end{array}$ & Area for experts/visitors to sign up. \\
\hline 5. & $\begin{array}{l}\text { Dashboard for } \\
\text { Experts }\end{array}$ & $\begin{array}{l}\text { Area for the experts, containing a gateway to features } \\
\text { like pay-per-call, one-to-one advice, video conferencing, } \\
\text { and video library management. }\end{array}$ \\
\hline
\end{tabular}




\begin{tabular}{|l|l|l|}
\hline 6. & Dashboard for Users & $\begin{array}{l}\text { Area for users, from where they can chose any mode to } \\
\text { communicate with their respective experts. }\end{array}$ \\
\hline 7. & Contacts & Visitors may send any query or comment from this page. \\
\hline
\end{tabular}

Table 1: Mapping of the E-Family Expert Website

Source: Authors and website designers

When people suffer marital discord, they can visit this platform to seek assistance via the numerous resources provided. Users can enrich their knowledge of how to handle marital discord without violating the law. If they want to connect with experts, they are provided with direct access to psychologists, counsellors, and religious experts. In case they require mediation or arbitration, there are panel dispute resolution experts who can be engaged for such endeavours. And in extreme cases, where there is need for litigation, the platform provides access to leading law firms and lawyers who can conduct preliminary reviews of the case before proceeding. A condition to be listed on the platform is that each law firm should annually undertake a certain number of pro bono cases, catering to the needs of less privileged clients.

\section{Incorporating the E-Family Experts Model into the National Legislative Framework: Malaysia as a Case Study}

In Malaysia, all government-provided family and marriage counselling services are offered physically, with no offline alternatives. ${ }^{17}$ In terms of incorporating the discussed E-Family Expert Model into existing shariah judiciary platforms, it appears that nothing much can be done unless Jabatan Kehakiman Syariah Malaysia (JKSM, 'Department of the Shariah Judiciary Malaysia') and the respective state authorities adopt guidelines into their current legislating frameworks mandating that parties explore sulh before approaching the court in family disputes. In this respect, the Islamic Family Law (Federal Territories) Act 1984 (or IFLA 1984) ${ }^{18}$ introduced a framework for hakam (arbitration) and conciliatory committees. Thus, Section 47(5) of IFLA 1984 provides for the appointment of a conciliatory committee by a shariah court if one of the parties does not consent to divorce or it appears to the court that there is a reasonable possibility of reconciliation..$^{19}$ This is in line with the legal text of the Qur'an, as provided in 4:35, which encourages reconciliation, as held in Siti Hawa bte Mohamed v. Mohamed Radzuan. ${ }^{20}$ In a similar vein, in Ramizah Haneem v. Yusuf Bin Hasbullah, ${ }^{21}$ the husband applied to a shariah court for divorce under Section 47 of IFLA 1984, but without his wife agreeing to divorce. The court therefore appointed a conciliatory committee to attempt a reconcilation 
in accordance with Section 45(5) of IFLA 1984. During the pendency of the proceedings, however, the husband pronounced divorce by a single talaq, allegedly before two witnesses, but in the absence of the wife. The latter was then informed of this development about two months later. In order to confirm the talaq, the husband applied to the shariah court, which did so relying solely on the statement of the husband. The court neither heard the wife nor the witnesses. The wife therefore appealed against the decision, which was allowed by Ahmad Ibrahim, who emphasised that the procedure set out in Section 47 of IFLA 1984 had not been followed. He further observed:

The learned judge in this case did not refer to the proceedings before the conciliatory committee and what progress was made in the effort to achieve reconciliation. The Act gives the conciliatory committee a period of six months from the date of its being constituted or such further period as may be allowed by the court. The learned judge did not state whether the period of six months had expired or whether he had extended the period. ${ }^{22}$

The appeal court therefore set aside the order of the judge from the lower court, ordering instead that the latter should refer to the report or certificate of the appointed conciliatory committee. ${ }^{23}$

According to the framework introduced by IFLA 1984, the second stage in any attempt to resolve a marital dispute is the appointment of hakam (arbitrators). Section 48 of IFLA 1984 makes this provision, ${ }^{24}$ stating that when the court is satisfied that there are constant quarrels, marital discord, or the husband could not be procured to pronounce talaq after reconciliation has failed, ${ }^{25}$ the court will appoint two arbitrators to act for the husband and the wife respectively in accordance with Islamic law. ${ }^{26}$ Preference will be given to close relatives of the parties involved, who have knowledge of the circumstances of the case. ${ }^{27}$ Nevertheless, the appointment of hakam may be subject to the discretion of the court. With usage of the phrase "the Court may appoint", this step is considered mandatory, since the same provision states that such an appointment is in accordance with Islamic law. ${ }^{28}$

In order to streamline and unify the practice and procedure of sulh as a court-annexed mediation process across Malaysia, its modus operandi has been introduced through court rules. The procedural rules for sulh were made pursuant to the powers of the Shariah Court Rules Committee, as provided for in Section 247(1)(c) of the Shariah Court Civil Procedure (Federal Territories) Act 1998. 
Within this context, the National Technical Committee on Shariah and Civil Law drafted the procedural rules for sulh in order "to coordinate the implementation and ensure the effectiveness of the mediation process." ${ }^{29}$ This draft was named the Civil Procedure (Sulh) (Federal Territories) Rules 1998. ${ }^{30}$ The release of the Practice Direction No. 3 of 2002 by the JKSM extended the application of sulh to all states in Malaysia. ${ }^{31}$ The Rules eventually came into force on 8 January 2004, as the Shariah Court Civil Procedure (Sulh) (Federal Territories) Rules 2004. ${ }^{32}$ Accordingly, the E-Family platform proposed here, with its pool of accredited experts, could be utilised for the purpose of conciliatory committees, hakam, and sulh when properly deployed within this legal framework.

While Malaysia seems to have a supportive legislative framework for the implementation of the E-Family Expert Model, other OIC countries should consider how such a platform can be accommodated under their existing laws. In some instances, these may need to be amended to allow for a mandatory condition necessitating the possibility of amicable settlement using the platform. In other cases, where couples require counselling, the court officials could refer parties to the E-Family Expert platform.

\section{Conclusion and Policy Recommendations}

This study has established the significance of embracing the opportunity ICT provides when responding to the urgent needs of couples undergoing difficult times in their marital relationships. While ODR has been utilised for various kinds of dispute, particularly in e-commerce related settings, one cannot but emphasise the contemporary relevance of this form of dispute resolution for family-related issues. The COVID experience has exposed the family institution to unprecedented threats, aggravated by continuous lockdowns and the negative psychological effects of COVID fatalities. Even after movement restrictions have been lifted, courts are unable to cope with the astronomical surge in family-related cases. Therefore, the E-Family Expert platform proposed here would, if developed further, help resolve such disputes remotely, easing familyrelated disagreements through counselling strategies administered by accredited experts.

This study will go a long way towards building a formidable family institution capable of promoting peace and cohesion within society, particularly within OIC member countries. This is the hallmark of Islamic law, which seeks to proactively address family-related disputes in innovative ways. In the modern sense, this could include the deployment of ICT in the form of ODR. When actualising this potential, however, there is a need to develop national 
policies and an enabling legal framework. Some countries, like Malaysia, have introduced mandatory processes to be followed before the litigation of family-related disputes is initiated. Such processes should be augmented by the E-Family Expert platform, such that courts require disputing parties to utilise that platform before approaching them.

Future studies should focus on practical case studies, where family disputes are resolved via virtual intervention. Other potential areas of study could include the development of the platform in real time, from prototype to a full-blown platform. However, before doing this, there is a need to further investigate perceptions of online-based platforms as consultation mediums, especially regarding the resolution of family-related disputes. This investigation should be carried out using the Technology Acceptance Model (TAM) and the Unified Theory of Acceptance and Use of Technology (UTAUT). These will help us better understand whether potential users would accept the E-Family Expert platform. It is expected that such research on intention to use will help improve the platform and its design.

\section{Notes}

* Zaleha Kamaruddin, is a Professor of Comparative Family Law at the International Islamic University Malaysia.

** Umar A. Oseni, a former Associate Professor of Law at the International Islamic University Malaysia.

*** Zati Ilham Abdul Manaf, is the corresponding author and an Assistant Professor at Ahmad Ibrahim Kulliyyah of Laws, International Islamic University Malaysia. She can be contacted at: ilham@iium.edu.my.

The authors extend their deepest appreciation to the Ministry of Higher Education, Malaysia, for funding this paper and related research work via the Fundamental Research Grant Scheme (FRGS/2/2013/SSI10/UIAM/01/1).

1. UN Women, UNFPA and Quilt.ai, 'COVID-19 and Violence Against Women: The Evidence Behind the Talk: Insights from Big Data Analysis in Asian Countries,' March 2021. Available at: https://asiapacific.unfpa.org/sites/default/ files/pub-pdf/covid-19_and_vaw_insights_from_big_data_analysis_final.pdf

2. Ibid.

3. The dedicated team led by Professor Dato' Dr. Zaleha Kamaruddin established and designed the E-Family Portal platform in 2014. Originally a prototype, it has been further enhanced and implemented on a wider scale with the recent experience of the pandemic. Though the website is not currently active, its design is ready and can be deployed at any time, once all necessary refinements have been made. 
4. M. Ethan Katsh, 'ODR: A Look at History' in Online Dispute Resolution: Theory and Practice, ed. Mohamed S. Abdel Wahab, Ethan Katsh and Daniel Rainey (The Hague: Eleven International Publishing, 2012), 9-21.

5. See generally, M. Ethan Katsh, 'Dispute Resolution in Cyberspace,' Conn. L. Rev. 28 (1995): 953-80.

6. Melissa H. Conley Tyler and Mark W. McPherson, 'Online Dispute Resolution and Family Disputes,' Journal of Family Studies 12, no. 2 (2006): 165-83.

7. Mark Thomson, 'Alternative Modes of Delivery for Family Dispute Resolution: The Telephone Dispute Resolution Service and The Online FDR Project1,' Journal of Family Studies 17, no. 3 (2011): 253-57.

8. Queensland Attorney General's Department and Relationships Australia, Development and Evaluation of Online Family Dispute Resolution Capabilities (2011). Available at: http://www.ag.gov.au/FamiliesAndMarriage/Families/ FamilyLawSystem/Documents/Archived\%20family\%20law\%20publications/ Development $\% 20$ and $\% 20$ Evaluation $\% 20$ of $\% 20$ Online $\% 20$ Family $\% 20$ Dispute\%20Resolution\%20Capabilities\%20.pdf (Accessed on: 23 July 2013).

9. Francesco Bonchi, Carlos Castillo, Aristides Gionis, and Alejandro Jaimes, 'Social Network Analysis and Mining for Business Applications,' ACM Transactions on Intelligent Systems and Technology (TIST) 2, no. 3 (2011): 1-37.

10. Brooke Abrahams, Emilia Bellucci, and John Zeleznikow, 'Incorporating Fairness into Development of an Integrated Multi-Agent Online Dispute Resolution Environment,' Group Decision and Negotiation 21, no. 1 (2012): 3-28.

11. Colin Rule, 'Online Dispute Resolution and the Future of Family Law,' Family Lawyer Magazine. Available at: https://familylawyermagazine.com/articles/ online-dispute-resolution-and-the-future-of-family-law. (Accessed on: $17 \mathrm{March}$ 2020).

12. Ibid.

13. Qur'an, 4: 128. (Emphasis added)

14. Qur'an, 4:35.

15. Ibn Kathir, n. 56, vol. 7 at 375.

16. Muhammad Hashim Kamali, Principles of Islamic Jurisprudence, $2^{\text {nd }}$ ed. (Kuala Lumpur: Ilmiah Publications, 1998), 311.

17. Details of family and marriage counselling services are available from the Ministry of Women, Family and Community Development website. Jabatan Kemajuan Islam Malaysia have also introduced an online platform called the 'Sistem Pengurusan Perkahwinan Islam Malaysia' for Muslim couples to arrange an appointment with the relevant state Islamic Religious Department for consultation services.

18. There are corresponding Islamic Family Law Enactments across the states in Malaysia, all modelled after the IFLA 1984 (Act 303). These enactments include: Islamic Family Law Enactment 1990 (Johor) (No. 5 of 1990); Islamic Family Law Enactment 2002 (Kelantan) (No. 6 of 2002); Islamic Family Law (State of Malacca) Enactment 2002 (No. 12 of 2002); Islamic Family Law (Negeri Sembilan) Enactment 2003 (No. 11 of 2003); Islamic Family Law Enactment 1987 (Pahang) (No. 3 of 1987); Islamic Family Law (State of Penang) Enactment 2004 (No. 5 of 2004); Islamic Family Law (Perak) Enactment 2004 (No. 6 of 
2004); Islamic Family Law Enactment 1992 (Perlis) (No. 4 of 1992); Islamic Family Law Enactment 1992 (Sabah) (No. 15 of 1992); Islamic Family Law Ordinance 2001 (Sarawak) (Cap 43); Islamic Family Law (State of Selangor) Enactment 2003 (No. 2 of 2003); Administration of Islamic Family Law Enactment 1985 (Terengganu) (No. 12 of 1985).

19. See a corresponding provision in section 47(5) of the Selangor Islamic Family Law Enactment 1984. However, there are exceptions to the application of section 47(5) and these are provided in section 47(15) of IFLA 1984, which provides: "The requirement of subsection (5) as to reference to a conciliatory committee shall not apply in any case-

a. where the applicant alleges that he or she has been deserted by and does not know the whereabouts of the other party;

b. where the other party is residing outside Peninsular Malaysia and it is unlikely that he or she will be within the jurisdiction of the Court within six months after the date of the application;

c. where the other party is imprisoned for a term of three years or more;

d. where the applicant alleges that the other party is suffering from incurable mental illness; or

e. where the Court is satisfied that there are exceptional circumstances which make reference to a conciliatory committee impracticable."

20. [1992] 1 MLJ cxcix.

21. [1993] 1 MLJA 115; [1993] 1 MLJA 115.

22. Id, 116.

23. Id, 119. See a similar case where the conciliatory committee was appointment but its efforts at reconciliation were unsuccessful: Siti Rohani bte Muhamad Yusufv Mohd Sazali bin Derham [1993] 2 MLJ 1.

24. Ahmad Ibrahim, Family Law in Malaysia, $3^{\text {rd }}$ ed. (Kuala Lumpur: Malayan Law Journal, 1997), 241. Also see Nehaluddin Ahmad, 'A Critical Appraisal of Triple Divorce by Examining if it is Sanctioned by the Holy Qur'an or the Sunnah,' [2008] 6 MLJ i; [2008] 6 MLJA 1, 11.

25. Nora Abdul Hak, 'Hakam/Tahkim (Arbitration) in Resolving Family Disputes: The Practice in the Syariah Courts of Malaysia and Singapore,'Asian Journal of International Law 1 No. 1 (2006): 47.

26. Section 48(1) of IFLA 1984.

27. Section 48(2) of IFLA 1984.

28. Section 48(1) of IFLA provides: “(1) If satisfied that there are constant quarrels (shiqaq) between the parties to a marriage, the Court may appoint in accordance with Hukum Syarak two arbitrators or Hakam to act for the husband and wife respectively." For the different views of jurists and other Muslim countries, see Abdul Hak, 'Hakam/Tahkim' 48-50.

29. Raihanah Azahari, 'The Development of Family Mediation in Malaysian Muslim Society,' European Journal of Social Sciences 18, no. 2 (2010): 227.

30. Ibid.

31. Ibid. Other Practice Directions relating to sulh issued by JKSM include Practice Direction No. 8 of 2003 on Procedure for Service of the sulh Notice; Practice Direction No. 11 of 2005 on the Jurisdiction of Syariah Subordinate Court to Record the Mediation and the Consent Agreement; Practice Direction No. 4 of 
2006 on Consent Agreement for Mediation; and Practice Direction No. 5 of 2006 on Effect of the Consent Agreement For Mediation.

32. PU (A) 18/ 2004.

\section{Bibliography}

Abdul Hak, Nora 'Hakam/Tahkim (Arbitration) in Resolving Family Disputes: The Practice in the Syariah Courts of Malaysia and Singapore.' Asian Journal of International Law 1 No. 1 (2006): 43-47.

Abrahams, Brooke, Emilia Bellucci, and John Zeleznikow. 'Incorporating Fairness Into Development of an Integrated Multi-Agent Online Dispute Resolution Environment.' Group Decision and Negotiation 21, no. 1 (2012): 3-28.

Ahmad, Nehaluddin. 'A Critical Appraisal of Triple Divorce by Examining if it is Sanctioned by the Holy Quran or the Sunnah.' [2008] 6 MLJ i; [2008] 6 MLJA 1,11 .

Azahari, Raihanah. 'The Development of Family Mediation in Malaysian Muslim Society.' European Journal of Social Sciences 18, no. 2 (2010): 227.

Bonchi, Francesco, Carlos Castillo, Aristides Gionis, and Alejandro Jaimes. 'Social Network Analysis and Mining for Business Applications.' ACM Transactions on Intelligent Systems and Technology (TIST) 2, no. 3 (2011): 1-37.

Queensland Attorney General's Department and Relationships Australia. Development and Evaluation of Online Family Dispute Resolution Capabilities 2001. http://www.ag.gov.au/FamiliesAndMarriage/Families/ FamilyLawSystem/Documents/Archived\%20family\%20law\%20publications/ Development $\% 20$ and $\% 20$ Evaluation $\% 20$ of $\% 20$ Online $\% 20$ Family $\% 20$ Dispute\%20Resolution\%20Capabilities\%20.pdf

Ibrahim, Ahmad. Family Law in Malaysia, $3^{\text {rd }}$. Kuala Lumpur: Malayan Law Journal Sdn. Bhd. 1997.

Kamali, Muhammad Hashim. Principles of Islamic Jurisprudence, $2^{\text {nd }}$ edition. Kuala Lumpur: Ilmiah Publishers, 1998.

Katsh, M. Ethan. 'Dispute Resolution in Cyberspace.' Conn. L. Rev. 28 (1995): 953-80.

Katsh, M. Ethan. 'ODR: A Look at History.' In Online Dispute Resolution: Theory and Practice. Edited by Mohamed S. Abdel Wahab, Ethan Katsh and Daniel Rainey. The Hague: Eleven International Publishing, 2012.

Rule, Colin. 'Online Dispute Resolution and the Future of Family Law.' Family Lawyer Magazine. Available at: https:/familylawyermagazine.com/articles/ online-dispute-resolution-and-the-future-of-family-law/

Thomson, Mark. 'Alternative Modes of Delivery for Family Dispute Resolution: The Telephone Dispute Resolution Service and the Online FDR Project1.' 
Journal of Family Studies 17, no. 3 (2011): 253-57.

Tyler, Melissa H. C., and Mark W. McPherson. 'Online Dispute Resolution and Family Disputes.' Journal of Family Studies 12, no. 2 (2006): 165-83.

UN Women, UNFPA and Quilt.ai. 'Covid-19 and Violence Against Women: The Evidence Behind the Talk: Insights from Big Data Analysis in Asian Countries.' Available at: https://asiapacific.unfpa.org/sites/default/files/pub-pdf/covid-19 and_vaw_insights_from_big_data_analysis_final.pdf 